ARTICLE OPEN

Check for updates

\title{
The efficacy of chlorine-based disinfectants against planktonic and biofilm bacteria for decentralised point-of-use drinking
}

\section{water}

\author{
Gillian E. Clayton (D), Robin M. S. Thorn ${ }^{1}$ and Darren M. Reynolds $\mathbb{( D D}^{1 凶}$
}

\begin{abstract}
Chlorine solutions are used extensively for the production of biologically safe drinking water. The capability of point-of-use [POU] drinking water treatment systems has gained interest in locations where centralised treatment systems and distribution networks are not practical. This study investigated the antimicrobial and anti-biofilm activity of three chlorine-based disinfectants (hypochlorite ions $\left[\mathrm{OCl}^{-}\right]$, hypochlorous acid [HOCl] and electrochemically activated solutions [ECAS]) for use in POU drinking water applications. The relative antimicrobial activity was compared within bactericidal suspension assays (BS EN 1040 and BS EN 1276) using Escherichia coli. The anti-biofilm activity was compared utilising established sessile Pseudomonas aeruginosa within a Centre for Disease Control $[C D C]$ biofilm reactor. $\mathrm{HOCl}$ exhibited the greatest antimicrobial activity against planktonic $E$. coli at $>50 \mathrm{mg} \mathrm{L}^{-1}$ free chlorine, in the presence of organic loading (bovine serum albumen). However, ECAS exhibited significantly greater anti-biofilm activity compared to $\mathrm{OCl}^{-}$and $\mathrm{HOCl}$ against $P$. aeruginosa biofilms at $\geq 50 \mathrm{mg} \mathrm{L}^{-1}$ free chlorine. Based on this evidence disinfectants where $\mathrm{HOCl}$ is the dominant chlorine species ( $\mathrm{HOCl}$ and ECAS) would be appropriate alternative chlorine-based disinfectants for POU drinking water applications.
\end{abstract}

npj Clean Water (2021)4:48; https://doi.org/10.1038/s41545-021-00139-w

\section{INTRODUCTION}

A major source of human disease is via the consumption of biologically contaminated water ${ }^{1}$. This is especially relevant for low income (i.e. Gross National Income [GNI] per capita is $<\$ 1025$ ) and least developed countries (46 low-income countries confronting severe structural impediments to sustainable development) where an estimated $30 \%$ of populations, on average, have access to basic sanitation services ${ }^{2}$. This is in contrast to upper-middle (GNI per capita \$4036-\$12,475) and high-income countries (GNI per capita $>\$ 12,476$ ) which predominantly utilise centralised drinking water treatment systems to ensure the production and supply of biologically safe water ${ }^{3}$. The primary role of drinking water disinfection is to control pathogenic microorganisms and to ensure that treated water is biologically safe to drink. Chlorine, in the form of sodium hypochlorite [NaOCl], is the most common disinfectant due to low cost and effective antimicrobial properties $^{4}$. The presence of residual chlorine $\left(0.5-5 \mathrm{mg} \mathrm{L}^{-1}\right)$ within redistribution networks limits microbial re-growth, helping to maintain biologically safe water at the point of delivery ${ }^{3}$. Indicator organisms such as Escherichia coli, total coliforms, Enterococci and Clostridium perfingens ${ }^{3,5}$, that infer the presence of faecal matter, are monitored to ensure the effectiveness of disinfection treatment processes. The recommended limit for these indicator organisms in treated water is zero CFU $100 \mathrm{~mL}^{-1}$, due to their potential pathogenic nature ${ }^{3,5}$. Unfortunately, the use of chlorine disinfectants gives rise to the formation of disinfection byproducts $[\mathrm{DBPs}]^{6,7}$ such as trihalomethanes ${ }^{8}$ and haloacetic acids ${ }^{9}$. Such by-products are known to exhibit mutagenic and carcinogenic properties ${ }^{10}$ and are therefore highly undesirable.

Point-of-use [POU] drinking water treatment systems do not require distribution networks and therefore negate the need to maintain residual chlorine levels. The World Health Organization recommends free chlorine concentrations of between 0.2 and
$0.5 \mathrm{mg} \mathrm{L}^{-1}$ at point of delivery and $\mathrm{use}^{3}$. The use of conventional chlorine-based disinfectants, such as hypochlorite $\left(\mathrm{OCl}^{-}\right)$, within POU water disinfection requires the storage and transportation of hazardous chemicals and can also cause the formation of harmful DBPs and the deterioration of taste and odour ${ }^{11}$. Ultraviolet and ozone are well established as disinfection technologies within both decentralised/POU ${ }^{12,13}$ and large scale drinking water treatment ${ }^{14,15}$, but an added benefit of implementing electrochemcially activated solutions [ECAS] is it has capability to be used externally to water treatment systems as part of food production $^{16,17}$ or in healthcare settings ${ }^{18,19}$. A limited number of studies have compared ECAS against commonly used chlorine agents for decentralised disinfection applications ${ }^{20,21}$. Although these preliminary studies were promising, neither study reported the $\mathrm{pH}$ of the ECAS studied or their effectiveness against biofilms.

Electrochemical disinfection technologies are emerging within the water sector 8,22 , and are currently well established in the food sector ${ }^{16,17}$, and to a lesser extent, in clinical/healthcare settings ${ }^{18,19}$. The generation of ECAS has previously been described in detail ${ }^{19}$ and are generated by passing a saline solution through an electrochemical cell with separate anodic and cathodic compartments. Anodic solutions are highly oxidative with oxidation-reduction potential [ORP] values greater than $+1000 \mathrm{mV}^{23,24}$. At these ORP values, anodic solutions are acidic in nature ( $\mathrm{pH}$ between 2 and 5) as a result of oxidative transient (metastable) antimicrobial species which form at the surface of the anode. At acidic $\mathrm{pH}$ values, the main antimicrobial chemical species are dominated by hypochlorous acid [HOCl] $(>95 \%)$, and dissolved chlorine $\left[\mathrm{Cl}_{2}\right](<5 \%)^{25,26}$. Additional metastable antimicrobial species including; $\mathrm{OH}^{-}, \mathrm{O}_{3}, \mathrm{H}_{2} \mathrm{O}_{2}$ and $\mathrm{O}_{2}^{-}$are also theorised to be generated although there lifetime and activity within active solutions is debated ${ }^{27,28}$. The antimicrobial properties of ECAS result from a combination of $\mathrm{HOCl}$ and the metastable

\footnotetext{
${ }^{1}$ Centre for Research in Biosciences, University of the West of England, Bristol BS16 1QY, UK. ${ }^{凶}$ email: Darren.Reynolds@uwe.ac.uk
} 
species that give rise to the observed high ORP values. The mode of action of such solutions is then physical rupture of the inner and outer cell membranes ${ }^{19,29}$, leading to disruption and failure of microbial functionality, such as energy generation mechanisms ${ }^{23}$.

Rather than exist in the planktonic state, it is now understood that most microorganisms attach to surfaces or substrates and establish sessile communities known as biofilms ${ }^{30,31}$. Naturally occurring biofilms contain multispecies microorganisms including bacteria, algae, fungi and protozoa, encased in an extracellular polymeric substance [EPS] $]^{32,33}$ as an adaptation to protect against external stresses, such as disinfectants including chlorine. The presence of biofilms within drinking water treatment systems is seen as an area of concern for maintaining water quality ${ }^{34,35}$. The formation of biofilm on infrastructure, such as pipes and filters, result in biofouling which can reduce operational time and lead to the corrosion of materials ${ }^{36,37}$. In particular, biofilms are known to act as reservoirs for pathogens ${ }^{38}$, through the shedding of daughter cells into bulk water supplies. Waterborne pathogens are often derived from faecal contamination (e.g. E. coli O157:H7) and can result in potentially fatal gastrointestinal [GI] diseases when left untreated, moreover opportunistic pathogens (e.g. Campylobacter species, Legionella species and Pseudomonas aeruginosa) can result in respiratory or $\mathrm{Gl}$ infections and diseases ${ }^{38}$. Of growing concern is the decreasing susceptibility of bacteria within biofilms to antimicrobials. Evidence has revealed that reactive chlorine species e.g. $\mathrm{OCl}^{-}$, are unable to penetrate the extracellular polymeric matrix of biofilms sufficiently to exert an effective biocidal action 39,40 .

The main aim of this study was to investigate the antimicrobial activity and biofilm inhibition of $\mathrm{OCl}^{-}, \mathrm{HOCl}$ and ECAS for use in POU drinking water systems. The bactericidal activities of $\mathrm{OCl}^{-}$, $\mathrm{HOCl}$ and ECAS were compared using standard chemical disinfectant assays utilising Escherichia coli as a model pathogenic organism, in the context of reducing the microbial load in bulk water. In addition, this study also investigated the efficacy of $\mathrm{OCl}^{-}$, $\mathrm{HOCl}$ and ECAS at reducing the density of established Pseudomonas aeruginosa biofilms.

\section{RESULTS \\ BS EN bactericidal suspension assays-reducing microbial load in bulk water}

The antimicrobial activity of the three test disinfectants against $E$. coli ATCC 10536 was assessed using standard bactericidal methods BS EN 1040 and $1276^{41,42}$. Within both methods, a 5 -log reduction of the target organism is the minimum threshold required to define the product as having bactericidal activity, as defined by the experimental parameters, either in the presence (BS EN 1276) or absence (BS EN 1040) of an organic load. This requires a greater starting inoculum $\left(8.54 \pm 0.27 \log 10 \mathrm{CFU} \mathrm{mL} \mathrm{mL}^{-1}\right)$ than what would be expected from E.coli present in input waters for POU drinking water treatment systems ( 2.06 $\pm 1.91 \log _{10}$ CFU $\left.100 \mathrm{~mL}^{-1}\right)^{43}$.

Figure 1 shows the antimicrobial activity of the $\mathrm{OCl}^{-}, \mathrm{HOCl}$ and ECAS against $E$. coli with no organic load (BS EN 1040) present. At free chlorine $(F C)$ concentrations $\geq 50 \mathrm{mg} \mathrm{L}^{-1}$, all disinfectants

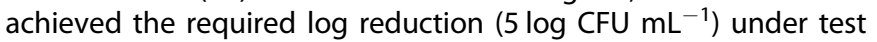
assay conditions ${ }^{41}$. At a FC concentration of $25 \mathrm{mg} \mathrm{L}^{-1}, \mathrm{OCl}^{-}$ exhibited significantly reduced antimicrobial activity compared to both ECAS and $\mathrm{HOCl}(p<0.0001)$. For $\mathrm{OCl}^{-}$, reduction of $3.80 \pm$ $1.246 \log _{10} \mathrm{CFU} \mathrm{mL} \mathrm{mL}^{-1}$ was observed, which is well below the required 5 -log reduction to define a product as having bactericidal activity, as defined by the conditions of the test assay undertaken. At this same concentration $\left(25 \mathrm{mg} \mathrm{L}^{-1} \mathrm{FC}\right), \mathrm{HOCl}$ resulted in a complete log reduction $\left(7.366 \pm 0.048 \log _{10} \mathrm{CFU} \mathrm{mL} \mathrm{mL}^{-1}\right)$, whereas ECAS resulted in a reduction of $5.676 \pm 0.807 \log _{10}$ CFU mL $\mathrm{mL}^{-1}$. Table 1 shows the CT values for a 5 -log reduction of $E$. coli for
$\mathrm{NaOCl}, \mathrm{HOCl}$ and ECAS. CT values are the product of the concentration of a disinfectant (e.g. free active chlorine) and the contact time with the water being disinfected. The CT value of

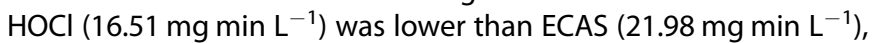
and approximately half that of $\mathrm{NaOCl}\left(33.81 \mathrm{mg} \mathrm{min}^{-1}\right)$, when no inhibitory solution is present. These $\mathrm{CT}$ values indicate that ECAS and $\mathrm{OCl}^{-}$require greater $\mathrm{FC}$ concentrations or contact time for an equivalent log reduction, compared to $\mathrm{HOCl}$.

Figure 2 shows the antimicrobial activity of the three disinfectants in the presence of a low concentration interfering (clean) organic load $\left(0.3 \mathrm{~g} \mathrm{~L}^{-1}\right.$ bovine serum albumen [BSA]). The highest FC concentration tested $\left(150 \mathrm{mg} \mathrm{L}^{-1}\right)$, resulted in complete log reductions for $\mathrm{NaOCl}\left(7.30 \pm 0.019 \log _{10} \mathrm{CFU} \mathrm{mL} \mathrm{mL}^{-1}\right)$ and $\mathrm{HOCl}\left(7.30 \pm 0.072 \log _{10} \mathrm{CFU} \mathrm{mL}^{-1}\right)$, whilst ECAS resulted in a $6.96 \pm 1.536 \log _{10} \mathrm{CFU} \mathrm{mL} \mathrm{m}^{-1}$ reduction. Therefore, all disinfectants demonstrated bactericidal activity in the presence of an organic load according to the conditions of the test (BS EN 1276). At $100 \mathrm{mg} \mathrm{L}^{-1} \mathrm{FC}$, all disinfectants exhibited a significant antimicrobial effect ( $>5$-log reduction) and there was no significant difference between the three disinfectants, whereby $\mathrm{HOCl}$ resulted in a complete log reduction, for $\mathrm{OCl}^{-}$a log reduction of $7.871 \pm 0.74 \log _{10}$ CFU mL $\mathrm{m}^{-1}$ was achieved whilst ECAS achieved a $6.806 \pm 1.09 \log _{10} \mathrm{CFU} \mathrm{mL} \mathrm{m}^{-1}$ reduction. At $50 \mathrm{mg} \mathrm{L}^{-1} \mathrm{FC}_{\text {, OCl }}^{-}$did not achieve the required 5-log reduction $\left(4.531 \pm 0.15 \log _{10}\right.$ CFU $\mathrm{mL}^{-1}$ ), resulting in significantly lower antimicrobial activity compared to both $\mathrm{HOCl}$ and ECAS $(p<0.0001)$, whereby there was no significant difference between $\mathrm{HOCl}$ and ECAS treatment $(p>0.05)$. At the lowest FC concentration tested $\left(25 \mathrm{mg} \mathrm{L}^{-1}\right)$ ECAS was the only disinfectant to reduce the bacterial load $\geq 5 \log _{10}$ CFU $\mathrm{mL}^{-1}$ (Fig. 2), resulting in a $6.077 \pm 1.441 \log _{10} \mathrm{CFU} \mathrm{\textrm {mL } ^ { - 1 }}$ log reduction. The log reductions obtained for $\mathrm{OCl}^{-}$and $\mathrm{HOCl}$ treatment were both significantly less than ECAS $(p<0.001)$, whereby $\mathrm{HOCl}$ resulted in a $3.207 \pm 0.505 \log _{10} \mathrm{CFU} \mathrm{mL} \mathrm{mL}^{-1} \log$ reduction, which was significantly greater than the $1.945 \pm 0.222$ $\log _{10} \mathrm{CFU} \mathrm{mL}-1$ log reduction exhibited by $\mathrm{OCl}^{-}(p=0.0011)$. The 5-log reduction $\mathrm{CT}$ values for $\mathrm{OCl}^{-}, \mathrm{HOCl}$ and ECAS with a low organic load demonstrated that $\mathrm{NaOCl}$ exhibited the highest $\mathrm{CT}$

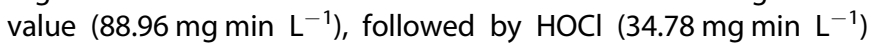

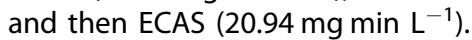

When the interfering substance concentration was increased from $0.3 \mathrm{~g} \mathrm{~L}^{-1}$ (clean BSA conditions) to $3.0 \mathrm{~g} \mathrm{~L}^{-1}$ (dirty BSA conditions) within the test assay, there was a significant impact on the antimicrobial activity exhibited by all three disinfectants (Fig. 3 and Table 1). The antimicrobial activity of both $\mathrm{OCl}^{-}$and ECAS was significantly reduced compared to respective values under clean conditions $(p<0.0001)$ at all FC concentrations tested. $\mathrm{HOCl}$ exhibited significantly greater antimicrobial activity compared to both $\mathrm{OCl}^{-}$and ECAS at 50, 100 and $150 \mathrm{mg} \mathrm{L}^{-1} \mathrm{FC}(p<0.01)$, with ECAS exhibiting significantly greater antimicrobial activity compared to $\mathrm{NaOCl}(p<0.05)$. This is reflected in the CT values (Table 1 ), whereby the $5 \mathrm{log}$ reduction $\mathrm{CT}$ value for $\mathrm{HOCl}$ is $82.91 \mathrm{mg} \mathrm{min}$ $\mathrm{L}^{-1}$, whilst $\mathrm{CT}$ values were unable to be calculated for $\mathrm{NaOCl}$ or ECAS under these experimental conditions due to insufficient antimicrobial activity at the end of the 5-minute contact time. At the lowest FC concentration tested $\left(25 \mathrm{mg} \mathrm{L}^{-1}\right)$, there was no significant difference in antimicrobial activity between the three disinfectants tested $(p>0.05)$. However, ECAS resulted in the greatest log reduction $\left(1.606 \pm 0.954 \log _{10} \mathrm{CFU} \mathrm{mL} \mathrm{mL}^{-1}\right)$, followed by $\mathrm{HOCl}\left(0.978 \pm 0.202 \log _{10} \mathrm{CFU} \mathrm{mL} \mathrm{mL}^{-1}\right)$ and $\mathrm{OCl}^{-}\left(0.025 \pm 0.004 \log _{10}\right.$

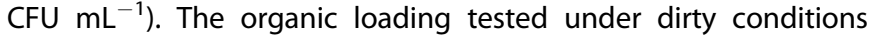
does not represent concentrations expected within POU drinking water systems. However, results highlight the need to reduce organics present to ensure sufficient antimicrobial activity throughout disinfection stages of drinking water treatment. 
Biofilm assays-reducing the density of established biofilms The antimicrobial activity of $\mathrm{OCl}^{-}, \mathrm{HOCl}$ and ECAS was determined against established Pseudomonas aeruginosa biofilms on polycarbonate $[P C]$ coupons as a function of the FC concentration (Fig. 4). The mean biofilm density recovered from untreated (no disinfectant treatment) control polycarbonate coupons was $8.45 \pm$ $0.172 \log _{10}$ CFU coupon ${ }^{-1}(n=18)$. None of the test disinfectants $\left(\mathrm{OCl}^{-}, \mathrm{HOCl}\right.$ or ECAS) resulted in complete log reduction at any $\mathrm{FC}$ concentration tested. At a FC concentration of $150 \mathrm{mg} \mathrm{L}^{-1}$ the greatest reduction in biofilm density was elicited by ECAS $(3.852 \pm$ $0.914 \log _{10} \mathrm{CFU}$ coupon $\left.{ }^{-1}\right)$, whereas $\mathrm{OCl}^{-}$and $\mathrm{HOCl}$ exhibited significantly lower log reductions $(p<0.0001)$ of $2.018 \pm 0.393$ $\log _{10}$ CFU coupon ${ }^{-1}$ and $2.005 \pm 0.419 \log _{10}$ CFU coupon ${ }^{-1}$, respectively. ECAS also exhibited significantly greater antimicrobial activity compared to $\mathrm{OCl}^{-}$and $\mathrm{HOCl}$ at 100,75 and $50 \mathrm{mg} \mathrm{L}^{-1}$ FC $(p<0.01)$. This is reflected in the CT values for a $2-\log (99 \%)$ reduction in biofilm density (see Table 1). The CT value for ECAS

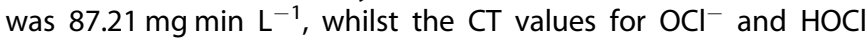
could not be determined as a 2-log reduction was not achieved at any of the FC concentrations tested. However, at FC concentrations of 25 and $5 \mathrm{mg} \mathrm{L}^{-1}$, there was no significant difference in the antimicrobial activity exhibited by $\mathrm{NaOCl}, \mathrm{HOCl}$ and ECAS $(p>$ $0.05)$. In fact, there was no significant reduction in biofilm density between 0 (control) and $5 \mathrm{mg} \mathrm{L}^{-1} \mathrm{FC}(p>0.05)$ for any test disinfectant. Overall, the results demonstrate a dose-response of

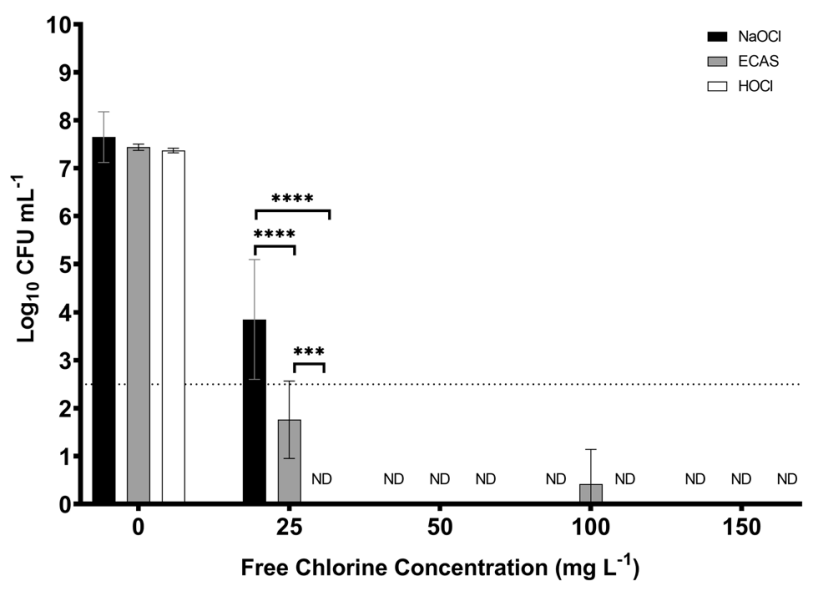

Fig. 1 Antimicrobial efficacy of $\mathrm{NaOCl}$, ECAS and $\mathrm{HOCl}$ against planktonic Escherichia coli with no inhibitory solution. Antimicrobial efficacy of $\mathrm{NaOCl}$ [black], ECAS [grey] and $\mathrm{HOCl}$ [white] using standardised free chlorine concentrations against $E$. coli ATCC 10536, and assessed using BS EN $1040\left({ }^{41}\right.$ British Standards Institution, 2005a). Dotted line represents the minimum log reduction (5 log CFU $\mathrm{mL}^{-1}$ ) required to demonstrate basic bactericidal activity under the experimental conditions of the assay $(n=3 \pm$ standard deviation [s.d.]). Significant differences ( $p$-values) calculated through a twoway ANOVA with Tukey's comparison post-test, with a confidence interval of $\left.95 \%{ }^{* * * *} p<0.0001{ }^{* * *} p<0.001\right)$. ND $=$ not detected. Error bars represent standard deviation. increasing antimicrobial efficacy with increasing FC concentrations. Interestingly, for ECAS the greatest increase in antimicrobial activity $\left(p=0.009\right.$ ) occurred at $\geq 25 \mathrm{mg} \mathrm{L}^{-1} \mathrm{FC}$, whereas the greatest increases for $\mathrm{HOCl}$ and $\mathrm{OCl}^{-}$were observed between 0 and $25 \mathrm{mg} \mathrm{L}^{-1}(p<0.0001)$.

\section{DISCUSSION}

Previously studies have compared the antimicrobial activity of common drinking water disinfectants, including $\mathrm{OCl}^{-}$, chlorine dioxide, ozone and chloramines in the context of centralised and distribution networks ${ }^{44,45}$. This study directly compared the antimicrobial activity of $\mathrm{OCl}^{-}, \mathrm{HOCl}$ and ECAS solutions against planktonic and bacterial biofilms for potential POU drinking water applications.

The data reported here demonstrate that all disinfectants exhibited significant antimicrobial activity against planktonic $E$. coli compared to the control. In the presence of no inhibitory substances (i.e. no organic load), all disinfectants exhibit an antimicrobial dose-response with increasing FC concentrations. At FC concentrations $\geq 50 \mathrm{mg} \mathrm{L}^{-1}$ there was no significant difference between the antimicrobial activity of $\mathrm{OCl}^{-}, \mathrm{HOCl}$ or ECAS. Whereas, at $25 \mathrm{mg} \mathrm{L}^{-1} \mathrm{FC}, \mathrm{HOCl}$ exhibited the greatest antimicrobial activity, followed by $\mathrm{OCl}^{-}$and ECAS. Observed differences in antimicrobial activity can be explained by the differing chemistry of the test disinfectants. All three disinfectants result in the production of $\mathrm{FC}$, the underlying chemistry of release being dependent on the chemical formulation and the physicochemical parameters (notably $\mathrm{pH}$ ), as dictated by the Nernst equation ${ }^{19}$. For example, the antimicrobial mechanisms (and therefore kinetics) in which $\mathrm{FC}$ is released differs between $\mathrm{NaOCl}$ (sodium hypochlorite) and NaDCC (sodium dichloroisocyanurate). The dissolution of $\mathrm{NaOCl}(\mathrm{pH} 11.4)$, primarily results in the formation of $\mathrm{OCl}^{-}$, whereas, dissolution of $\mathrm{NaDCC}(\mathrm{pH} \mathrm{5.6)}$, primarily results in the formation of $\mathrm{HOCl}^{25,46}$. For ECAS ( $\mathrm{pH} 3.3$ ), dissolution results in a mixture of chlorine species; including $\mathrm{HOCl}$ and dissolved $\mathrm{Cl}_{2}$, with $\mathrm{HOCl}$ being the dominant species. Additional metastable antimicrobial species are also theorised to be formed ${ }^{28}$, consequently resulting in ECAS having the highest ORP of the three test disinfectants $(+1134 \mathrm{mV})$. Chlorine-based disinfectants where $\mathrm{OCl}^{-}$ is the dominant chlorine species have shown to be less efficacious, due to inefficient diffusion through the lipid bilayer of cell membranes, therefore oxidation only occurs at the outer cell envelope ${ }^{47}$. By contrast, $\mathrm{HOCl}$ is able to penetrate through the outer envelope, and diffuse through the inner plasma membrane as a result of its electrical neutrality ${ }^{47}$. This results in internal oxidative damage to key cellular functions, such as energy generation, as well as damage to bacterial DNA ${ }^{23,29}$.

The negative impact of organic loading on oxidising disinfectants is well known ${ }^{47,48}$. Within this study, the presence of lowconcentration organic material reveals differences in the dose responses that arise from the differing mechanisms of action exhibited by $\mathrm{OCl}^{-}, \mathrm{HOCl}$ and ECAS. The half-life $\left(\mathrm{DT}_{50}\right)$ of $\mathrm{OCl}^{-}$ions is greatly reduced by several orders of magnitude from minutes to seconds ${ }^{49}$ and this explains the reduction in efficacy seen for

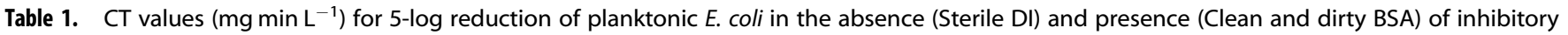
solutions and a 2-log reduction of $P$. aeruginosa biofilm.

\begin{tabular}{llllll}
\hline Disinfectant & $\mathrm{pH}$ & Planktonic E. coli (Sterile DI) & Planktonic E. coli (Clean BSA) & Planktonic E. coli (Dirty BSA) & P. aeruginosa biofilm \\
\hline ECAS & $3.3 \pm 0.16$ & 21.97 & 20.94 & $\mathrm{ND}^{\mathrm{a}}$ & 87.21 \\
$\mathrm{HOCl}$ & $5.6 \pm 0.25$ & 16.51 & 34.78 & 82.91 & $\mathrm{ND}^{\mathrm{a}}$ \\
$\mathrm{NaOCl}$ & $11.4 \pm 0.1$ & 33.81 & 73.27 & $\mathrm{ND}^{\mathrm{a}}$ & $\mathrm{ND}^{\mathrm{a}}$ \\
\hline
\end{tabular}

FC concentrations were determined by linear regression, and contact time was 5 min for all reactions.

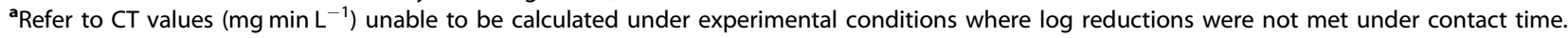




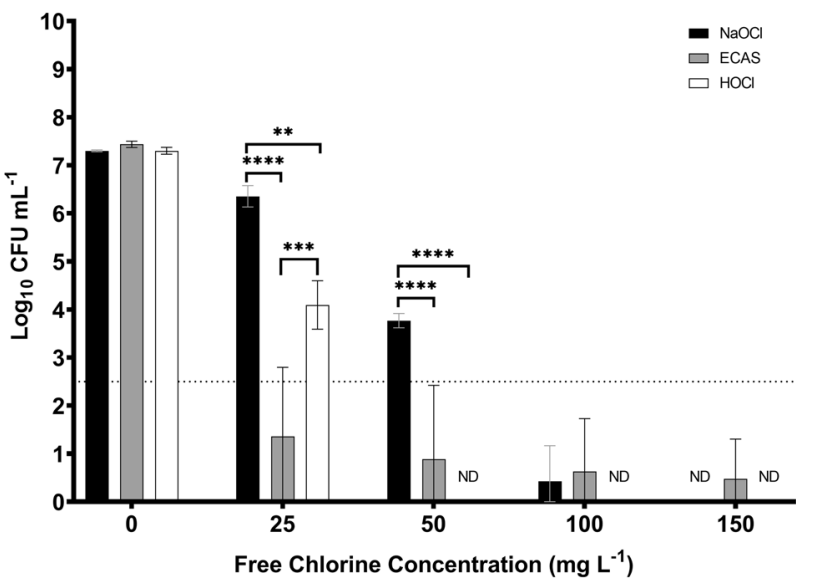

Fig. 2 Antimicrobial efficacy of $\mathrm{NaOCl}$, ECAS and $\mathrm{HOCl}$ against planktonic Escherichia coli with Clean BSA as an inhibitory solution. Antimicrobial efficacy of $\mathrm{NaOCl}$ [black], ECAS [grey] and $\mathrm{HOCl}$ [white] using standardised free chlorine concentrations against $E$. coli ATCC 10536 with an interfering solution of $0.3 \mathrm{~g} \mathrm{~L}^{-1}$ BSA ( ${ }^{42}$ British Standards Institution,2009). Dotted line represents the minimum log reduction ( $5 \mathrm{log} C F U \mathrm{~mL}^{-1}$ ) required to demonstrate basic bactericidal activity under the experimental conditions of the assay ( $n=3 \pm$ s.d.). Significant differences ( $p$-values) calculated through a two-way ANOVA with Tukey's comparison post-test, with a confidence interval of $95 \%\left({ }^{* * * *} p<0.0001 ;{ }^{* * *} p<0.001 ;{ }^{* *} p<0.01\right)$. $\mathrm{ND}=$ not detected. Error bars represent standard deviation.

$\mathrm{NaOCl}$ even under clean BSA conditions (Figs. 2, 3). For $\mathrm{HOCl}$, the antimicrobial activity was significantly reduced at $25 \mathrm{mg} \mathrm{L}^{-1} \mathrm{FC}$ under clean BSA conditions, but not at concentrations $>25 \mathrm{mg} \mathrm{L}^{-1}$ (i.e. $50,100,150 \mathrm{mg} \mathrm{L}^{-1}$ ). Interestingly, there was no significant difference in the antimicrobial activity exhibited by ECAS at an FC concentration of $25 \mathrm{mg} \mathrm{L}^{-1}$ in either the presence or absence of low organic loading (clean BSA conditions). This shows that low concentrations of organic matter do not unduly interfere with the mechanism of action for ECAS under these experimental conditions. ECAS exhibits very high ORP value $(>+1100 \mathrm{mV})$, due to both reactive chlorine and oxygen species, which in turn drives rapid oxidation reactions. However, the presence of higher concentrations of organic matter will ultimately reduce the ORP through oxidation-reduction reactions ${ }^{50}$, contributing to a resultant reduction in antimicrobial activity of ECAS, as has been previously observed ${ }^{50,51}$. Interestingly, previous work by Robinson et al. in $2013^{52}$ demonstrated that antimicrobial activity of ECAS could be maintained when stored for a 398 day period at $4{ }^{\circ} \mathrm{C}$ in the dark, despite showing no detectable FC after 277 days (e.g. < $0.01 \mathrm{mg} \mathrm{L}^{-1}$ ). This demonstrates the importance of the additional antimicrobial species, other than those that are chlorine derived, contributing to an increased antimicrobial activity. Thus, helping explain the greater antimicrobial activity of ECAS at a FC of $25 \mathrm{mg}$ $\mathrm{L}^{-1}$ in the presence of clean BSA conditions when compared to equivalent $\mathrm{HOCl}$ and $\mathrm{NaOCl}$ solutions. Further increasing the organic loading of BSA ( $3.0 \mathrm{~g} \mathrm{~L}^{-1}$; dirty BSA conditions) within the bactericidal assay greatly reduced the antimicrobial activity of $\mathrm{OCl}^{-}$ and ECAS at all FC concentrations tested. In comparison the antimicrobial activity of $\mathrm{HOCl}$ was not significantly reduced at $\mathrm{FC}$ concentrations $>25 \mathrm{mg} \mathrm{L}^{-1}$. Therefore, it is clear that $\mathrm{HOCl}$ produced via the dissolution of NaDCC demonstrates a greater antimicrobial activity against planktonic bacteria under dirty BSA conditions. Chemically derived $\mathrm{HOCl}$ is more stable than electrochemically generated $\mathrm{HOCl}$ solutions, as they do not possess metastable antimicrobial species, that form at the anodic surface $^{53}$. Chemically derived $\mathrm{HOCl}$ also degrades at a slower rate when exposed to sunlight (UV) ${ }^{54}$, in comparison to electrochemically generated $\mathrm{HOCl}$ which degrade at an increased rate $\mathrm{r}^{55}$. This highlights the importance of selecting the most appropriate

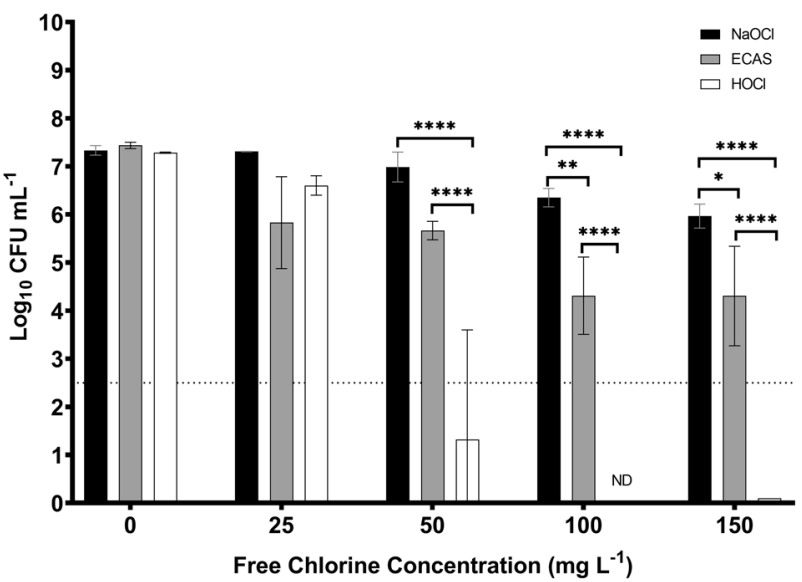

Fig. 3 Antimicrobial efficacy of $\mathrm{NaOCl}$, ECAS and $\mathrm{HOCl}$ against planktonic Escherichia coli with Dirty BSA as an inhibitory solution. Antimicrobial efficacy of $\mathrm{NaOCl}$ [black], ECAS [grey] and $\mathrm{HOCl}$ [white] using standardised free chlorine concentrations against $E$. coli ATCC 10536 with an interfering solution of $3.0 \mathrm{~g} \mathrm{~L}^{-1}$ BSA $\left({ }^{42}\right.$ British Standards Institution, 2009). Dotted line represents the minimum log reduction ( 5 log CFU $\mathrm{mL}^{-1}$ ) required to demonstrate basic bactericidal activity under the experimental conditions of the assay $(n=3 \pm$ s.d.). Significant differences ( $p$-values) calculated through a two-way ANOVA with Tukey's comparison post-test, with a confidence interval of $95 \%\left({ }^{* * * *} p<0.0001 ;{ }^{* *} p<0.01 ;{ }^{*} p<0.05\right)$. $\mathrm{ND}=$ not detected. Error bars represent standard deviation.

disinfectant for use in POU treatment systems. For example, in instances where filtration or removal of organic matter from bulk water is not standard practice or is difficult, $\mathrm{HOCl}$ would provide greater antimicrobial efficacy, compared to $\mathrm{NaOCl}$ or ECAS.

Reducing microbial load in bulk waters will also reduce the formation of biofilms on infrastructure, as well as potentially reduce the density of established biofilms. Thus, the comparative antimicrobial activity of $\mathrm{OCl}^{-}, \mathrm{HOCl}$ and ECAS was also determined against established Pseudomonas aeruginosa biofilms on polycarbonate coupons. Equivalent reductions in biofilm density (and $\mathrm{CT}$ values), were observed for $\mathrm{OCl}^{-}$and $\mathrm{HOCl}$ at all $\mathrm{FC}$ concentrations tested. ECAS was the most efficacious disinfectant

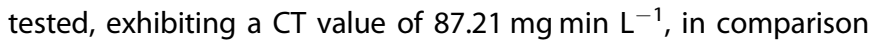
CT values could not be calculated for $\mathrm{OCl}^{-}$and $\mathrm{HOCl}$ as a 2-log reduction was not achieved for any of the FC concentrations tested. Antimicrobial disinfectants containing halogen species such as chlorine, have been shown to have a diminished efficacy on reducing biofilm cell density, as a result of reaction-diffusion and adsorption interactions with EPS matrix substances ${ }^{39,56}$. The high reactivity of $\mathrm{OCl}^{-}$contributes to its inefficiency against microbial biofilms, as it becomes rapidly neutralised through reaction with the EPS matrix, reducing its penetration, and thus, diffusion towards bacterial cells within biofilms ${ }^{40}$. Therefore, the concentration of halogen species available to react with the target microorganisms is reduced, thus increasing CT values ${ }^{40,57}$. Stewart \& Rayner et al. (2001) ${ }^{40}$ estimated that $\mathrm{OCl}^{-}$was 767 times slower at reducing a $P$. aeruginosa biofilm by $9.9 \log _{10} \mathrm{CFU} \mathrm{cm}^{-2}$ compared to an equivalent planktonic state.

The disinfectants tested against biofilms in this study demonstrate an antimicrobial dose-response with increasing FC concentrations. The dose-response curves for $\mathrm{OCl}^{-}$and $\mathrm{HOCl}$ did not differ significantly, whilst ECAS demonstrated significantly greater antibiofilm activity at FC concentrations $\geq 50 \mathrm{mg} \mathrm{L}^{-1}$ when compared to both $\mathrm{NaOCl}$ and $\mathrm{HOCl}(p \leq 0.0021)$. In contrast, against planktonic cells, $\mathrm{HOCl}$ demonstrated the greatest antimicrobial activity at FC concentrations $\geq 50 \mathrm{mg} \mathrm{L}^{-1}$ (Figs. 1-3). This observed reduced antimicrobial activity of $\mathrm{OCl}^{-}$and $\mathrm{HOCl}$ against biofilms is in agreement with previous studies, whereby the $C T$ values and tolerance factors are 10 or 100 times greater between planktonic 


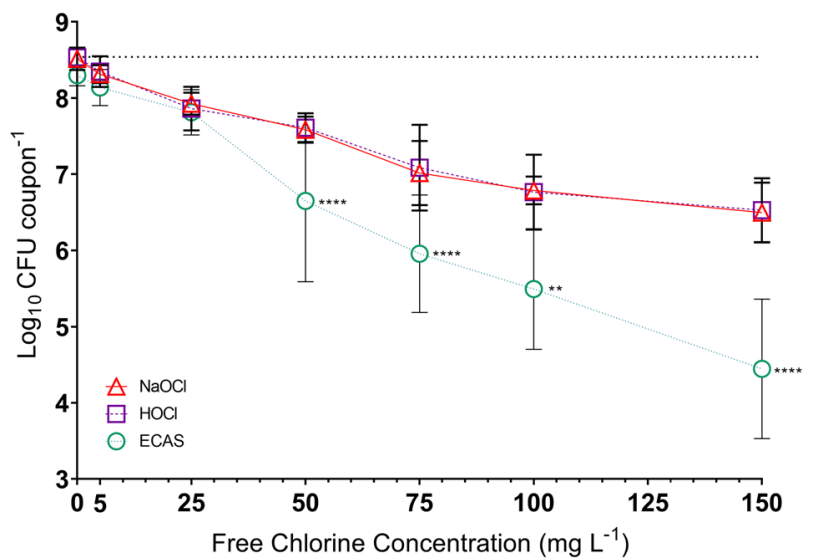

Fig. 4 Antimicrobial activity of $\mathrm{NaOCl}, \mathrm{ECAS}$ and $\mathrm{HOCl}$ against Pseudomonas aeruginosa biofilms. Antimicrobial activity of $\mathrm{NaOCl}$ $[\triangle], \mathrm{HOCl}[\mathrm{O}]$ and ECAS $[\mathrm{O}]$ using standardised $\mathrm{FC}$ concentrations against Pseudomonas aeruginosa ATCC 15442 biofilms $(n=9 \pm$ s.d.). $[\cdots]$ Refers to the recovered mean biofilm density (CFU coupon ${ }^{-1}$ ) from control (untreated) treatment $\left(0 \mathrm{mg} \mathrm{L}^{-1}\right) ; n=18$. Significant differences ( $p$-values) calculated through a two-way ANOVA with Tukey's comparison post-test, with a confidence interval of $95 \%$ $\left({ }^{* * *} p<0.0001 ;{ }^{* *} p<0.01\right)$. Error bars represent standard deviation.

and biofilm disinfection ${ }^{40,47}$. Both $\mathrm{OCl}^{-}$and $\mathrm{HOCl}$ are neutralised through reaction with biofilm EPS, due to their high reactivity ${ }^{40}$. Conversely, ECAS has been observed to have significant antibiofilm activity ${ }^{51,58}$. The anti-biofilm properties of acidic electrolysed water [EW] was determined by Ayebah et al. ${ }^{51}$ against Listeria monocytogenes biofilms resulting in a $4.5 \log _{10}$ reduction after 30 and $60 \mathrm{~s}$ contact times. The postulated antimicrobial mode of action for ECAS against microbial biofilms is two-fold. The high ORP (relative to $\mathrm{HOCl}$ and $\mathrm{OCl}^{-}$), indicative of its increased oxidation ability and metastable antimicrobial species $s^{4,28}$ disrupts the protective EPS barrier, which is composed of a complex mixture of polysaccharides, proteins and DNA ${ }^{59}$, through the destruction of covalent bonds within DNA, RNA and proteins ${ }^{60,61}$. In addition, the active chlorine species within ECAS, predominantly $\mathrm{HOCl}$, have no charge and so can penetrate through the EPS and react with the embedded bacterial cells ${ }^{47}$.

Overall, this study investigated the quantitative antimicrobial and anti-biofilm activity of three chlorine-based disinfectants against single-species planktonic and sessile (biofilm) bacteria for potential POU drinking water applications. Based on this data, $\mathrm{OCl}^{-}$ was shown to be the least effective against planktonic and sessile bacterial populations, $\mathrm{HOCl}$ was found to be the most effective at reducing (disinfecting) planktonic bacterial populations, and ECAS was most effective at reducing the density of established bacterial biofilms. It is worth noting that direct comparisons between the efficacy of $\mathrm{OCl}^{-}, \mathrm{HOCl}$ and ECAS between disinfecting planktonic $E$. coli populations and reducing $P$. aeruginosa biofilm density should be carried out with caution. Disinfection of planktonic $P$. aeruginosa was not carried out as it is not included as part of standard drinking water analysis, due to the view that it is an opportunistic pathogen. Conversely, investigating the reduction of E. coli biofilm density did not occur as it is not well known to form biofilms, unlike $P$. aeruginosa. It has previously been demonstrated that $\mathrm{HOCl}$ and ECAS interaction with organic matter (e.g. humic acids) does not result in the production of high concentrations of disinfection by-products, specifically trihalomethanes, unlike $\mathrm{OCl}^{-}{ }^{8}$. Therefore, in POU systems where removal of organic matter through filtration or coagulation is not common practice or possible, the implementation of $\mathrm{HOCl}$ or ECAS will not only effectively reduce microbial load in supply waters and help to manage biofilm formation, but will also minimise the formation of THMs ensuring the production of biologically and chemically safe drinking water. However, $\mathrm{HOCl}$ can be produced chemically through the dissolution of NaDCC (as shown in this study), but can also be generated electrochemically ${ }^{62}$. The ability to produce efficacious disinfectants in situ and on demand, minimises the need to transport and store hazardous chemicals, thus reducing the potential for accidental chemical release into the environment. The metastable nature of electrochemically generated $\mathrm{HOCl}$ (acidic or slightly acidic) can ensure that excess solutions can easily be deactivated through the exposure of organic material, as it chemically relaxes and reverts back to the original saline solution ${ }^{19}$. Electrochemically generated $\mathrm{HOCl}$ has been proven efficacious in a wide number of settings, including food production $^{16,22}$ and healthcare settings ${ }^{19}$, allowing one disinfectant to be safely used throughout a community, and not only for POU drinking water treatment applications which is not possible with other disinfection technologies, such as UV, ozone and granular activated carbon. Electrochemically generated $\mathrm{HOCl}$ could provide superior antimicrobial activity alongside increased anti-biofilm activity (an important consideration within POU drinking water treatment infrastructure), however, its use within POU applications requires further investigation. A limitation of this study is that residual free chlorine concentrations were not monitored post-bactericidal or biofilm reduction assays. To ensure that free concentrations in POU drinking water treatment systems do not exceed required WHO concentrations $\left(0.2-0.5 \mathrm{mg} \mathrm{L}^{-1}\right)$, future studies will monitor residual chlorine concentration postbactericidal or biofilm reduction assays.

This study has helped advance our understanding of chlorinebased disinfectants for POU drinking water applications. However, source waters supplying POU systems are far more complex than that tested here, with a variety of organic material and numerous microbial species present, particularly given that bacteria seldom exist in single-species communities in the environment ${ }^{63}$. Therefore, investigating multispecies cultures/biofilms, within more complex matrices as part of representative model systems, is required to further our understanding of the antimicrobial activity and suitability of the disinfectants tested for applications in POU drinking water treatment. Such models should test different material surfaces that represent the variety of POU drinking water treatment systems (e.g. pipework or filters) that could affect biofilm formation.

\section{METHODS}

\section{Test disinfection solutions}

Three disinfectants were used throughout this study: $\mathrm{NaOCl}$, neutral slightly acidic $\mathrm{HOCl}$ and electrochemically generated acidic $\mathrm{HOCl}$. The dominant chlorine species present in $\mathrm{NaOCl}$ was $\mathrm{OCl}^{-}$, whereas $\mathrm{HOCl}$ was dominant in both the neutral and acidic $\mathrm{HOCl}$ solutions. The electrochemically generated acidic $\mathrm{HOCl}$ will be referred to as electrochemically activated solution [ECAS]. Stock solutions of $\mathrm{NaOCl}$ were prepared by diluting a commercial bleach (Pattersons bleach; Pattersons Ltd., Bristol, UK) in deionised water to a final free chlorine [FC] concentration of $508 \pm$ $18.19 \mathrm{mg} \mathrm{L}^{-1}$, with a mean $\mathrm{pH}$ of $11.4 \pm 0.1$, and a mean ORP of $+588 \pm$ $0.95 \mathrm{mV}$. Slightly acidic $\mathrm{HOCl}$ stock solution was prepared through the dissolution of NaDCC within 1 litre of deionised water producing a FC concentration of $201 \pm 13.55 \mathrm{mg} \mathrm{L}^{-1}$, with a $\mathrm{pH}$ of $5.6 \pm 0.25$, and a mean ORP of $+958 \pm 18.98 \mathrm{mV}$. ECAS was generated through the electrolysis of an $\mathrm{NaCl}$ solution using a $60 \mathrm{~L} / \mathrm{h}$ electrochemical generator supplied by Bridge Biotechnology Ltd (Fife, Scotland, UK). Solutions of ECAS with FC concentrations of $158.63 \pm 18.66 \mathrm{mg} \mathrm{L}^{-1}$, mean $\mathrm{pH}$ of $3.3 \pm 0.16$ and ORP of $+1134 \pm 3.26 \mathrm{mV}$ were generated and stored at $4{ }^{\circ} \mathrm{C}$ in the dark, and used within 5 days of production. All disinfectant solutions were diluted using deionised water to produce standardised equivalent FC concentrations as determined by $\mathrm{N}, \mathrm{N}$-diethyl-p-phenylenediamine sulphate (DPD) no. 1 Palintest test (Palintest Ltd., Gateshead, UK). The $\mathrm{pH}$ and ORP of solutions were measured using an Orion Dual Star (Fisher Scientific, UK). 


\section{6}

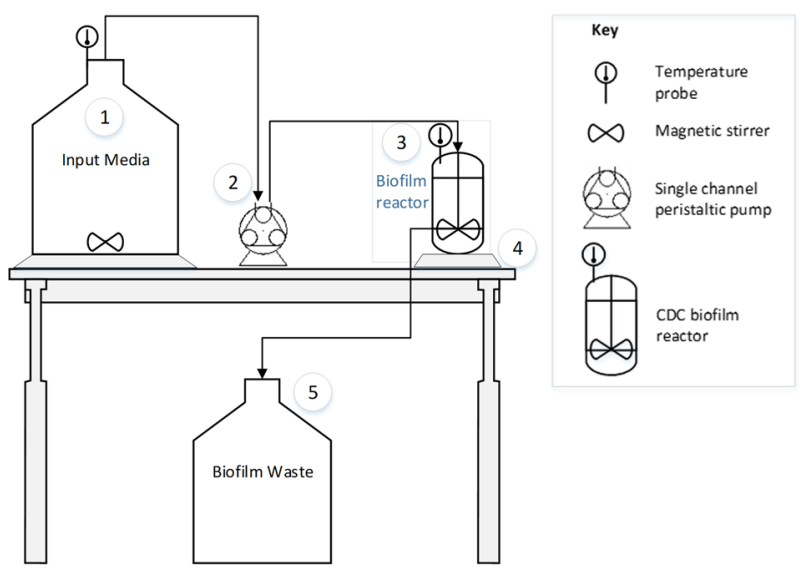

Fig. 5 Experimental set up of a Centre for Disease Control Biofilm Reactor. Standard experimental set-up of CDC biofilm reactor. Sterile input media (i.e. tryptone soya broth) is held within a $20 \mathrm{~L}$ Nalgene ${ }^{\mathrm{TM}}$ carboy [1], and drawn through a single channel peristaltic pump [2] towards the CDC biofilm reactor [3]. A heating stir plate [4] maintained constant temperature and shear force within the CDC reactor. A sterile Nalgene ${ }^{\mathrm{TM}}$ waste carboy collects CDC biofilm reactor waste [5].

\section{Bacterial cultures}

E. coli ATCC 10536 and P. aeruginosa ATCC 15422 were grown on Tryptone Soya Agar (TSA [Oxoid, Thermo Scientific, UK]) for $24 \mathrm{~h}$ at $37^{\circ} \mathrm{C}$ recovered from frozen stocks stored at $-80^{\circ} \mathrm{C}$.

\section{BS EN Bactericidal suspension assay}

Standard suspension assays for determining bactericidal activity of $\mathrm{NaOCl}$, $\mathrm{HOCl}$ and ECAS against E. coli were carried out according to BS EN 1040 $\left({ }^{41}\right.$ British Standards Institution, 2005) and BS EN $1276\left({ }^{42}\right.$ British Standards Institution, 2009). Standardised FC concentrations of 25, 50, 100 and $150 \mathrm{mg} \mathrm{L}^{-1}$ were used as treatment regimens for each of the test disinfectants (see Section 4.1).

As per BS EN 1040/1276 standard assays, bacterial suspensions of $E$. coli within diluent solution $\left(1 \mathrm{~g} \mathrm{~L}^{-1}\right.$ tryptone and $\left.8.5 \mathrm{~g} \mathrm{~L}^{-1} \mathrm{NaCl}\right)$ were

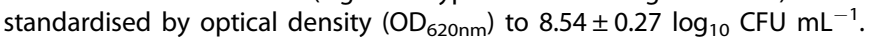
Where required, inhibitory solutions of (BSA) at two concentrations were

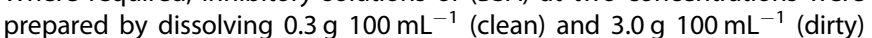
BSA, then filter sterilised through $0.45 \mu \mathrm{m}$ syringe filters (Sartorius Minisart ${ }^{\circledR}$ Syringe filters). This resulted in final assay BSA concentrations of $0.3 \mathrm{~g} \mathrm{~L}^{-1}$ (clean) and $3.0 \mathrm{~g} \mathrm{~L}^{-1}$ (dirty).

The assay was performed by mixing $1 \mathrm{~mL}$ of $E$. coli test suspension, with $1 \mathrm{~mL}$ of inhibitory solution (either sterile DI, clean or dirty BSA) and $8 \mathrm{~mL}$ of test disinfectant ( $\mathrm{NaOCl}, \mathrm{HOCl}$ or ECAS), for the specified contact time of $5 \mathrm{~min}$ at $20^{\circ} \mathrm{C}$. Subsequently, a $1 \mathrm{~mL}$ sample from the reaction vial (comprising of test suspension, inhibitory solution and test disinfectant) was immediately pipetted into $9 \mathrm{~mL}$ of a validated neutralising solution $\left(5 \mathrm{~g} \mathrm{~L}^{-1}\right.$ sodium thiosulphate and $27.5 \mathrm{~g} \mathrm{~L}^{-1}$ Letheen Broth; BD Difco, Becton Dickinson). Neutralised samples were serially diluted in sterile $\mathrm{DI}$, and plated in duplicate onto TSA (50 $\mu \mathrm{L}$ volume) using a Whitley Automated Spiral Plater ([WASP] Don Whitley Scientific, Shipley, UK). These were then incubated at $37^{\circ} \mathrm{C}$ for $24 \mathrm{~h}$ and resultant colonies counted (expressed as CFU per $\mathrm{mL}$ ).

\section{Biofilm assay}

The Centre for Disease Control [CDC] biofilm reactor (see Fig. 5); ${ }^{64}$ was used for growing and testing of $P$. aeruginosa biofilms on PC coupons (BioSurfaces Technologies, USA). Standardised FC concentrations of 5, 25, $50,75,100$ and $150 \mathrm{mg} \mathrm{L}^{-1}$ were used as treatment regimens for each of the test disinfectants (see Section 2.1).

The $P$. aeruginosa inoculum was cultured in $100 \mathrm{~mL}$ of $100 \mathrm{mg} \mathrm{L}^{-1}$ tryptone soya broth (TSB [CM0129; Oxoid, Thermo Scientific, UK]) within a shaking incubator for $24 \mathrm{~h}$ at $35^{\circ} \mathrm{C}$ at $150 \mathrm{rpm}$, resulting in a final microbial density of $7.79 \pm 0.17 \log _{10}$ CFU mL ${ }^{-1}(n=9)$. Sterile media ( $330 \mathrm{~mL}$ of TSB $100 \mathrm{mg} \mathrm{L}^{-1}$ ) was added into a sterile CDC reactor containing coupon rods, which housed 3 PC coupons per rod ( $n=8$ rods per reactor). The CDC reactor was placed on a heated stir plate (set to $22.5^{\circ} \mathrm{C}$ and continuously stirred at $125 \mathrm{rpm}), 1 \mathrm{~mL}$ of $P$. aeruginosa inoculum was added and incubated for $24 \mathrm{~h}$ (the batch phase), allowing bacteria to attach and establish biofilms on the PC coupons (contained within removal rods). Subsequently, continuous addition of sterile media (100 $\left.\mathrm{mg} \mathrm{L}^{-1} \mathrm{TSB}\right)$, drawn from a sterile $20 \mathrm{~L}$ autoclavable carboy (Nalgene ${ }^{\mathrm{TM}}$ 2250-0050; Fisher Scientific, UK), was introduced into the CDC reactor at a flow rate of $11 \mathrm{~mL}$ $\mathrm{min}^{-1}$ for an additional $24 \mathrm{~h}$. The volume within the CDC reactor during this period was maintained by an overflow weir connected to a waste media carboy. This method resulted in reproducible $P$. aeruginosa PC coupon biofilms at a density of $8.45 \pm 0.172 \log _{10}$ CFU coupon ${ }^{-1}(n=18)$, and therefore suitable for subsequent experimentation.

\section{Biofilm bacterial enumeration}

To enable assessment of the antimicrobial activity of the test disinfectants, $P$. aeruginosa PC coupon biofilms were aseptically removed from the CDC reactor and placed into $50 \mathrm{~mL}$ falcon tubes, containing $3 \mathrm{~mL}$ of test disinfectant or sterile DI (control). After a 5-minute contact time at room temperature, $27 \mathrm{~mL}$ of validated neutralising solution $\left(5 \mathrm{~g} \mathrm{~L}^{-1}\right.$ sodium thiosulphate and $27.5 \mathrm{~g} \mathrm{~L}^{-1}$ Letheen Broth) was added to all samples and left for a further $10 \mathrm{~min}$ at room temperature. Subsequently, to remove biofilm from the surface of the PC coupons, each falcon tube was vortexed for $30 \mathrm{~s}$, and then placed in a sonicating water bath (FB11078 FisherBrand) for $1 \mathrm{~min}$, this was repeated three times in total. The disaggregated biofilm cells were serially diluted in quarter strength Ringer's solution (Oxoid, Fisher Scientific, UK) and spiral plated onto R2A agar (Oxoid, Thermo Scientific, UK). Plates were incubated at $37^{\circ} \mathrm{C}$ for $24 \mathrm{~h}$ and resultant colonies counted and expressed as CFU per coupon.

\section{Data analysis}

$\mathrm{CT}$ values are the product of the concentration of a disinfectant (e.g. free active chlorine) and the contact time with the water being disinfected. CT values were calculated for the $5-\log (99.999 \%)$ reduction of planktonic $E$. coli and the $2-\log (99 \%)$ reduction of $P$. aeruginosa biofilm through linear regression, with a contact time of $5 \mathrm{~min}$ at room temperature $\left(20-22.5^{\circ} \mathrm{C}\right)$, and adjusted to be expressed as $\mathrm{mg} / \mathrm{min} \mathrm{L}^{-1}$.

For both the bactericidal and biofilm assay data sets, a two-way analysis of variance (ANOVA) with Tukey's post-test was used to determine significant differences between disinfectant type and FC concentration (GraphPad Prism version 7.0 for Windows, San Diego, CA). A $P$ value of $<$ 0.05 was regarded as significant.

\section{Reporting summary}

Further information on research design is available in the Nature Research Reporting Summary linked to this article.

\section{DATA AVAILABILITY}

All data generated or analysed during this study are included in this published article.

Received: 9 July 2021; Accepted: 8 October 2021; Published online: 04 November 2021

\section{REFERENCES}

1. Prüss-Ustün, A. et al. Burden of disease from inadequate water, sanitation and hygiene in low- and middle-income settings: a retrospective analysis of data from 145 countries. Trop. Med. Int. Heal. 19, 894-905 (2014).

2. WHO \& UNICEF. Progress on Drinking Water, Sanitation and Hygiene in Households 2000-2020: Five Years into the SDGs (WHO \& UNICEF, 2021).

3. World Health Organization. Guidelines for Drinking-water Quality 4th edn. (WHO, 2011) https://doi.org/10.1016/S1462-0758(00)00006-6.

4. Gil, M. I., Gómez-López, V. M., Hung, Y.-C. \& Allende, A. Potential of electrolyzed water as an alternative disinfectant agent in the fresh-cut industry. Food Bioprocess Technol. 8, 1336-1348 (2015).

5. Drinking Water Inspectorate. Guidance on the implementation of the water supply (water quality) regulations 2000 (as amended) in England. Drinking Water Inspectorate vol. 2000 (Drinking Water Inspectorate, 2012).

6. Chowdhury, S. Trihalomethanes in drinking water: effect of natural organic matter distribution. Water SA 39, 1-8 (2013). 
7. Grunwald, A., Nikolaou, A. D., Golfinopoulos, S. K. \& Lekkas, T. D. Formation of organic by-products during chlorination of natural waters. J. Environ. Monit. 4 910-916 (2002)

8. Clayton, G. E., Thorn, R. M. S. \& Reynolds, D. M. Comparison of trihalomethane formation using chlorine-based disinfectants within a model system; applications within point-of-use drinking water treatment. Front. Environ. Sci. 7, 35 (2019).

9. Malliarou, E., Collins, C., Graham, N. \& Nieuwenhuijsen, M. J. Haloacetic acids in drinking water in the United Kingdom. Water Res. 39, 2722-2730 (2005).

10. World Health Organization. Trihalomethanes in Drinking-water (World Health Organization, 2005).

11. Fawell, J. \& Nieuwenhuijsen, M. J. Contaminants in drinking water. Br. Med. Bull. 68, 199-208 (2003)

12. Carratalà, A. et al. Solar disinfection of viruses in polyethylene terephthalate bottles. Appl. Environ. Microbiol. 82, 279-288 (2016).

13. Zhu, J., Fan, X. J., Tao, Y., Wei, D. Q. \& Zhang, X. H. Study on an integrated process combining ozonation with ceramic ultra-filtration for decentralized supply of drinking water. J. Environ. Sci. Heal. 49, 1296-1303 (2014).

14. Glaze, W. H., Kang, J.-W. \& Chapin, D. H. The chemistry of water treatment processes involving ozone, hydrogen peroxide and ultraviolet radiation. Ozone Sci. Eng. 9, 335-352 (1987)

15. McGuire, M. J. Drinking Water Chlorination (American Chemistry Council, 2016). https://chlorine.americanchemistry.com/Chlorine-Benefits/Safe-Water/ Disinfection-Practices.pdf 10.1002/(SICI) 1521-401X(199902)27:2<100::AID AHEH100>3.3.CO;2-1.

16. Han, Q. et al. Removal of foodborne pathogen biofilms by acidic electrolyzed water. Front. Microbiol. 8, 1-12 (2017)

17. Thorn, R. M. S., Pendred, J. \& Reynolds, D. M. Assessing the antimicrobial potential of aerosolised electrochemically activated solutions (ECAS) for reducing the microbial bio-burden on fresh food produce held under cooled or cold storage conditions. Food Microbiol. 68, 41-50 (2017).

18. Kirkpatrick, R. D. The mechanism of antimicrobial action of Electro-Chemically Activated (ECA) water and its healthcare applications (University of Pretoria, 2009).

19. Thorn, R. M. S., Lee, S. W. H., Robinson, G. M., Greenman, J. \& Reynolds, D. M. Electrochemically activated solutions: evidence for antimicrobial efficacy and applications in healthcare environments. Eur. J. Clin. Microbiol. Infect. Dis. 31, 641-653 (2012).

20. Ghebremichael, K., Muchelemba, E., Petrusevski, B. \& Amy, G. Electrochemically activated water as an alternative to chlorine for decentralized disinfection. J. Water Supply.: Res. Technol._Aqua 60, 210-218 (2011).

21. Venczel, L. V., Likirdopulos, C. A., Robinson, C. E. \& Sobsey, M. D. Inactivation of enteric microbes in water by electro-chemical oxidant from brine $(\mathrm{NaCl})$ and free chlorine. Water Sci. Technol. 50, 141-146 (2004).

22. Kerwick, M. I., Reddy, S. M., Chamberlain, A. H. L. \& Holt, D. M. Electrochemica disinfection, an environmentally acceptable method of drinking water disinfection? Electrochim. Acta 50, 5270-5277 (2005).

23. Liao, L. B., Chen, W. M. \& Xiao, X. M. The generation and inactivation mechanism of oxidation-reduction potential of electrolyzed oxidizing water. J. Food Eng. 78, 1326-1332 (2007).

24. Robinson, G. M., Lee, S. W.-H., Greenman, J., Salisbury, V. C. \& Reynolds, D. M. Evaluation of the efficacy of electrochemically activated solutions against nosocomial pathogens and bacterial endospores. Lett. Appl. Microbiol. 50, 289-294 (2010)

25. Cherney, D. P., Duirk, S. E., Tarr, J. C. \& Collette, T. W. Monitoring the speciation of aqueous free chlorine from $\mathrm{pH} 1$ to 12 with Raman spectroscopy to determine the identity of the potent low-pH oxidant. Appl. Spectrosc. 60, 764-772 (2006).

26. Nakagawara, S. et al. Spectroscopic characterization and the $\mathrm{pH}$ dependence of bactericidal activity of the aqueous chlorine solution. Jpn. Soc. Anal. Sci. 14, 691-698 (1998)

27. Jeong, J., Kim, J. Y. \& Yoon, J. The role of reactive oxygen species in the electrochemical inactivation of microorganisms. Environ. Sci. Technol. 40, 3-4 (2006).

28. Martínez-Huitle, C. A. A., Brillas, E., Martinez-Huitle, C. A. \& Brillas, E. Electrochemical alternatives for drinking water disinfection. Angew. Chem. Int. Ed. 47, 1998-2005 (2008).

29. Inoue, Y. et al. Trial of electrolyzed strong acid aqueous solution lavage in the treatment of peritonitis and intraperitoneal abscess. Artif. Organs 21, 28-31 (1997)

30. Bernstein, R. et al. 'Should I stay or should I go?' Bacterial attachment vs biofilm formation on surface-modified membranes. Biofouling 30, 367-376 (2014).

31. Schwering, M., Song, J., Louie, M., Turner, R. J. \& Ceri, H. Multi-species biofilms defined from drinking water microorganisms provide increased protection against chlorine disinfection. Biofouling 29, 917-928 (2013).

32. O'Toole, G., Kaplan, H. B. \& Kolter, R. Biofilm formation as microbial development Annu. Rev. Microbiol. 54, 49-79 (2000).
33. Flemming, H.-C. C. et al. Biofilms: an emergent form of bacterial life. Nat. Rev. Microbiol. 14, 563-575 (2016).

34. Ashbolt, N. J. Microbial contamination of drinking water and human health from community water systems. Curr. Environ. Heal. Rep. 2, 95-106 (2015).

35. Skraber, S., Schijven, J., Gantzer, C. \& de Roda Husman, A. M. Pathogenic viruses in drinking-water biofilms: a public health risk? Biofilms 2, 105-117 (2005).

36. Crozes, G. F., Jacangelo, J. G., Anselme, C. \& Laîné, J. M. Impact of ultrafiltration operating conditions on membrane irreversible fouling. J. Memb. Sci. 124, 63-76 (1997).

37. Sillanpää, M. In Natural Organic Matter in Water 1-15 (Butterworth-Heinemann, 2015). https://doi.org/10.1016/B978-0-12-801503-2.00001-X.

38. Wingender, J. \& Flemming, H.-C. Biofilms in drinking water and their role as reservoir for pathogens. Int. J. Hyg. Environ. Health 214, 417-423 (2011).

39. De Beer, D., Srinivasan, R. \& Stewart, P. S. Direct measurement of chlorine penetration into biofilms during disinfection. Appl. Environ. Microbiol. 60, 4339-4344 (1994).

40. Stewart, P. S., Rayner, J., Roe, F. \& Rees, W. M. Biofilm penetration and disinfection efficacy of alkaline hypochlorite and chlorosulfamates. J. Appl. Microbiol. 91 525-532 (2001).

41. British Standards Institution. Chemical disinfectants and antiseptics-quantitative suspension test for the evaluation of basic bactericidal activity of chemical disinfectants and antiseptics - test method and requirements (phase 1). European Committee for Standardization vol. 3 http://www.cen.eu/cen/Sectors/ TechnicalCommitteesWorkshops/CENTechnicalCommittees/Pages/Standards. aspx?param $=6197 \&$ title $=$ Chemical disinfectants and antiseptics (2005).

42. British Standards Institution. Chemical disinfectants and antiseptics-Quantitative suspension test for the evaluation of bactericidal activity of chemical disinfectants and antiseptics used in food, industrial, domestic and institutional areas -Test method and requirements (phase 2, European Committee for Standardization vol. 3 http://www.cen.eu/cen/Sectors/TechnicalCommitteesWorkshops/ CENTechnicalCommittees/Pages/Standards.aspx?param=6197\&title=Chemical disinfectants and antiseptics (2009).

43. Clayton, G. E., Thorn, R. M. S. \& Reynolds, D. M. Development of a novel off-grid drinking water production system integrating electrochemically activated solutions and ultrafiltration membranes. J. Water Process Eng. 30, (2019)

44. Loret, J. F. et al. Comparison of disinfectants for biofilm, protozoa and Legionella control. J. Water Health 3, 423-433 (2005).

45. Diao, H., Li, X., Gu, J., Shi, H. \& Xie, Z. Electron microscopic investigation of the bactericidal action of electrochemical disinfection in comparison with chlorination, ozonation and Fenton reaction. Process Biochem. 39, 1421-1426 (2004).

46. Clasen, T. \& Edmondson, P. Sodium dichloroisocyanurate (NaDCC) tablets as an alternative to sodium hypochlorite for the routine treatment of drinking water at the household level. Int. J. Hyg. Environ. Health 209, 173-181 (2006).

47. Fukuzaki, S. Mechanisms of actions of sodium hypochlorite in cleaning and disinfection processes. Biocontrol Sci. 11, 147-157 (2006).

48. Bloomfield, S. F., Arthur, M., Looney, E., Begun, K. \& Patel, H. Comparative testing of disinfectant and antiseptic products using proposed European suspension testing methods. Lett. Appl. Microbiol. 13, 233-237 (1991).

49. European Chemicals Agency. Regulation (EU) No 528/2012 concerning the making available on the market and use of biocidal products. Active chlorine released from sodium hypochloriteProduct-type 4 (Food and feed area). https:// echa.europa.eu/documents/10162/3b7a78a9-9bda-f684-a088-418dc4a56adb (2017).

50. Oomori, T., Oka, T., Inuta, T. \& Arata, Y. The efficiency of disinfection of acidic electrolyzed water in the presence of organic materials. Anal. Sci. 16, 365-369 (2005).

51. Ayebah, B., Hung, Y.-C., Kim, C. \& Frank, J. F. Efficacy of electrolyzed water in the inactivation of planktonic and biofilm Listeria monocytogenes in the presence of organic matter. J. Food Prot. 69, 2143-2150 (2006).

52. Robinson, G., Thorn, R. \& Reynolds, D. The effect of long-term storage on the physiochemical and bactericidal properties of electrochemically activated solutions. Int. J. Mol. Sci. 14, 457-469 (2013).

53. Ignatov, I. et al. The evaluation of the mathematical model of interaction of electrochemically activated water solutions (anolyte and catholyte) with water Eur. Rev. Chem. Res. 4, 72-86 (2015).

54. Cotruvo, J., Giddings, M., Jackson, P., Magara, Y. \& Ohanian, E. Sodium Dichloroisocyanurate in Drinking-water (2007).

55. Xuan, X. et al. Storage stability of slightly acidic electrolyzed water and circulating electrolyzed water and their property changes after application. J. Food Sci. 81 E610-E617 (2016).

56. Richards, J. J. \& Melander, C. Controlling bacterial biofilms. ChemBioChem 10, 2287-2294 (2009).

57. Stewart, P. S. In Microbial Biofilms (eds. Mukherjee, P. K., Ghannoum, M., Whiteley, M. \& Parsek, M.) 269-286 (American Society of Microbiology, 2015). https://doi. org/10.1128/9781555817466. 
58. Kim, C., Hung, Y.-C., Bracket, R. E. \& Frank, J. F. Inactivation of listeria monocytogenes biofilms by electrolyzed oxidizing water. J. Food Process. Preserv. 25, 91-100 (2011).

59. Flemming, H. C. \& Wingender, J. The biofilm matrix. Nat. Rev. Microbiol. 8, 623-633 (2010).

60. Zinkevich, V., Beech, I. B., Tapper, R. \& Bogdarina, I. The effect of super-oxidized water on Escherichia coli. J. Hosp. Infect. 46, 153-156 (2000).

61. Cloete, T. E., Thantsha, M. S., Maluleke, M. R. \& Kirkpatrick, R. The antimicrobial mechanism of electrochemically activated water against Pseudomonas aeruginosa and Escherichia coli as determined by SDS-PAGE analysis. J. Appl. Microbiol. 107, 379-384 (2009).

62. Ding, T., Oh, D. H. \& Liu, D. Electrolyzed Water in Food: Fundamentals and Applications (2019). https://doi.org/10.1007/978-981-13-3807-6.

63. Hall-Stoodley, L., Costerton, J. W. \& Stoodley, P. Bacterial biofilms: from the natural environment to infectious diseases. Nat. Rev. Microbiol. 2, 95-108 (2004).

64. BioSurface Technologies Corp. CDC Biofilm Reactor Operator's Manual (BioSurface Technologies Corp.)

\section{ACKNOWLEDGEMENTS}

This study was funded by the Natural Environment Research Council, UK [NE/ R003106/1], the University of the West of England, Bristol, and Portsmouth Aviation Ltd.

\section{AUTHOR CONTRIBUTIONS}

G.E.C.: experimental method development, experimental work, data collection and analysis, manuscript preparation and writing, review and editing. R.M.S.T.: funding acquisition, experimental conceptualisation and development, project supervision and manuscript review and editing. D.M.R.: funding acquisition, experimental conceptualisation and development, project supervision and manuscript review and editing.

\section{COMPETING INTERESTS}

The authors declare that the research was conducted in the absence of any commercial or financial relationships that could be construed as a potential conflict of interest.

\section{ADDITIONAL INFORMATION}

Supplementary information The online version contains supplementary material available at https://doi.org/10.1038/s41545-021-00139-w.

Correspondence and requests for materials should be addressed to Darren $M$. Reynolds.

Reprints and permission information is available at http://www.nature.com/ reprints

Publisher's note Springer Nature remains neutral with regard to jurisdictional claims in published maps and institutional affiliations.

(i) Open Access This article is licensed under a Creative Commons Attribution 4.0 International License, which permits use, sharing, adaptation, distribution and reproduction in any medium or format, as long as you give appropriate credit to the original author(s) and the source, provide a link to the Creative Commons license, and indicate if changes were made. The images or other third party material in this article are included in the article's Creative Commons license, unless indicated otherwise in a credit line to the material. If material is not included in the article's Creative Commons license and your intended use is not permitted by statutory regulation or exceeds the permitted use, you will need to obtain permission directly from the copyright holder. To view a copy of this license, visit http://creativecommons. org/licenses/by/4.0/

(c) The Author(s) 2021 